OPEN ACCESS

Edited by:

Tom Crick,

Swansea University, United Kingdom

Reviewed by:

Adamantios Koumpis,

University of Passau, Germany

Mary Frances Rice,

University of New Mexico,

United States

*Correspondence:

Melvin Freestone

melvinfreestone@gmail.com

Specialty section:

This article was submitted to

Digital Education,

a section of the journal

Frontiers in Education

Received: 12 June 2019

Accepted: 29 August 2019

Published: 04 October 2019

Citation:

Freestone M and Mason J (2019)

Questions in Smart Digital

Environments. Front. Educ. 4:98

doi: 10.3389/feduc.2019.00098

\section{Questions in Smart Digital Environments}

\author{
Melvin Freestone ${ }^{*}$ and Jon Mason \\ International Graduate Centre of Education, College of Education, Charles Darwin University, Darwin, NT, Australia
}

Innovations in digital technologies have catalyzed significant transformations of teaching and learning. Searching static webpages has evolved into dynamic online social networking and user generated content, and more recently interaction with intelligent services. The distinguishing features are embodied in the keywords-search, social, and smart. While search engines maintain a pivotal role in the web, social media now rivals them for dominance. The current era of smart technologies, based around big data and artificial intelligence, further extends the frontier of possibilities. With transition to the "world of smart" in mind, we explore ways in which the natural human ability of questioning might be scaffolded and developed. Digital environments provide diverse opportunities to construct learning in ways that bring life inside and outside school closer together. They open-up new horizons for learners to engage in a curious dialogue with experience. Yet the answer driven paradigm of "search" abbreviates much of the scope for questioning embedded in the expression and growth of curiosity. In this paper, we describe a set of generic generative questions that has the potential to transform questioning in digital environments. In so doing, a conceptual analysis of how learners' questioning might be scaffolded is presented. Applicable to all areas of learning, these questions promote imaginative thinking and deep understanding on which knowledge building and creation is predicated. Question driven dialogues generate critical and creative thinking, and thereby help to enact current mandates for creativity and knowledge building. The conformity emanating from the Global Education Reform Movement is anomalous with prescriptive curriculum texts and standardized tests emphasizing answers, not questions. Clever use of digital environments has the potential to catalyze a shift toward a questions-based approach to teaching and learning.

Keywords: generative, questions, inquiry, pedagogy, smart, scaffolding, curious learning, curriculum

\section{CHALLENGING POSSIBILITIES}

Transition to the "world of smart" opens-up an array of possibilities for learners to engage in differentiated and personalized programs (Bray and McClaskey, 2017). Opportunities for multimodal learning (Moreno and Mayer, 2007; Nair, 2018) and collaboration create much scope for learners to express their talents and multiple intelligences (Gardner, 1983; Perveen, 2018). Yet much of the discourse remains answer driven, as distinct from question driven.

The diverse means for teaching and learning together with the scope for connectivity afforded by digital technologies has significant implications for curriculum and school practices. The interaction may include experts and organizations in the real-world outside school as well as communities of learners cooperating around shared projects and tasks within school settings. 
Ethical and safe use of online digital resources and social networking platforms also has the potential to give expression to- "Pupil voice" (Rudduck, 2004).

The paradox is the rise of standardized approaches to schooling around the world (Sahlberg, 2015) which has led to tightly regulated curriculum reform often linked to standardized testing. Many teachers feel constrained and teach to the tests (Popham, 2001). In this context, answers, not questions, are rewarded with mistakes regarded as a mark of failure. The conformity is anomalous when juxtaposed against the need for creativity and imagination in a world of rapid change (UNESCO, 2015). Indeed, it has been frequently argued that education today is going in the opposite direction to what is required (Robinson, 2010, 2011; Thomas and Brown, 2011; Spector, 2017; PendletonJullian et al., 2018).

If learning involves a curious dialogue with experience (Freire, 1970), exploring questions provokes possibility (Freestone, 2016). The challenge is for asking questions to become a central part of inquiries (Corley and Rauscher, 2013). Yet the questions teachers ask reflect schema in their minds, colored by what is set out in prescriptive curriculum texts. They tend to persist with the same question, or variations of it, until they receive answers that match their expectations (Guan Eng Ho, 2005). They also ask questions much more frequently than learners, repeatedly answering their own questions before learners have had time to construct answers (Cotton, 1998). Yet learners' questions are a resource that reflects and shapes their learning (Chin and Osborne, 2008; Rothstein and Santana, 2011).

Questions reflect a dialogue between critical and creative thinking (Figure 1). Tension between them generates understanding, cleverness and inventiveness, especially when explored through collaborative means (Bogler, 2018). The "connections" generated by questions mirror mental imaging that enact one's emerging thoughts (Brogaard and Gatzia, 2017). The imaging may be formulated and expressed in words, symbols, sounds, and visual pictures, or multimedia combinations of them (Paivio, 1986). These thoughts are often expressed by metaphorical means (Ricoeur, 1978; Lakoff, 1993) which include-narratives, similes, analogies, hypotheses, and metaphors.

At a moment in time numerous connections might come together to form a "concatenate of sense"-a unity of ordered and disordered thoughts (McGill and Parry, 1948)-only to be dissolved or consumed into something else or completely rethought as new possibilities are revealed. Brain-based research indicates that different "concatenates of sense" would likely be networked and interact in dynamic ways across the template of human consciousness (Sporns, 2010; Barrett and Satpute, 2013).

\section{GENERATIVE QUESTIONS}

The generic generative questions (GGQs) in Figure 2 can shape thinking as well as energize synthesis between different "concatenates of sense." The set, applicable to all fields of knowledge and experience, is an extension of those identified in the IBO (2000). Yet they remain abstractions until asked in specific contexts and for particular purposes. The dialogue required among learners and teachers helps to ensure the "consequent questions" identified are capable of investigation and reflect the thinking and mind-sets of those involved (Eris, 2003; Mason, 2014c, p. 12). The process becomes mature when learners explore questions they have formulated (Klanlari et al., 2017).

In the process learners ask "sense-making" questions (Mason, 2012, 2014a) which help them develop plausible images that reflect their thinking and inform how best to proceed. When these images are clear, inquiries become purposeful, which raises the possibility that formulation of "consequent questions" is a multi-faceted process of sense-making questions, development questions and culminating questions. Negotiation of "consequent questions" is integral to inquiries that focus on the "why" dimension in learning (Mason, 2014b; Khan and Mason, 2015). Maybe processes for devising these questions may need to be modeled, and perhaps taught (Graesser and Person, 1994; Graesser et al., 2010). Yet where a culture of curiosity and diversity are hallmarks, generative questions may be sufficient (Sullins et al., 2018).

Figure 2 also identifies some "curious relations," or areas of deep understanding, inherent within each of the GGQs. These are scalable to different levels of learning either to meet the requirements in extant curriculums and courses, or to address the needs and interests of learners, or to take advantage of the potential smart technologies have to enhance learning. The term "curious relations" signifies their problematic nature as well as their continuing sophistication with experience. Learning designed and built around them emphasizes conceptual understanding and application (Erickson, 2012). Accent on these relations might moderate overemphasis on facts and answers as well as alleviate some of the overcrowding in education programs.

GGQs together with the "curious relations" associated with them could provide a useful means of scaffolding learning and structuring digital environments aimed at building and creating knowledge (Mason, 2011); and thereby, help teachers and learners progress their learning from novice to expert (HmeloSilver et al., 2007; Belland, 2017). The examples that follow illustrate the potential of GGQs to direct and shape studies. *Each study could be pitched around the detailed advice set out in curriculum statements at system or school levels for particular years of schooling.

Example 1. A study focusing on being literate in multimedia styles and options.

If the GGQs selected were-What is it like? and Who might be responsible?-a "consequent question" might be-In what ways might the practices of advertisers be controlled? Subject-matters for inquiry might include investigation of the structure and appropriateness of the language used in print and visual media.

If the GGQs were-What is the ethical reasoning? and Why is it like it is? - a "consequent question" might be-In what ways are the ideas and information in this or that media production authentic and reliable? Subject-matters for inquiry might include investigation of the visual imagery and language used in a documentary or a TV program or different News items. 


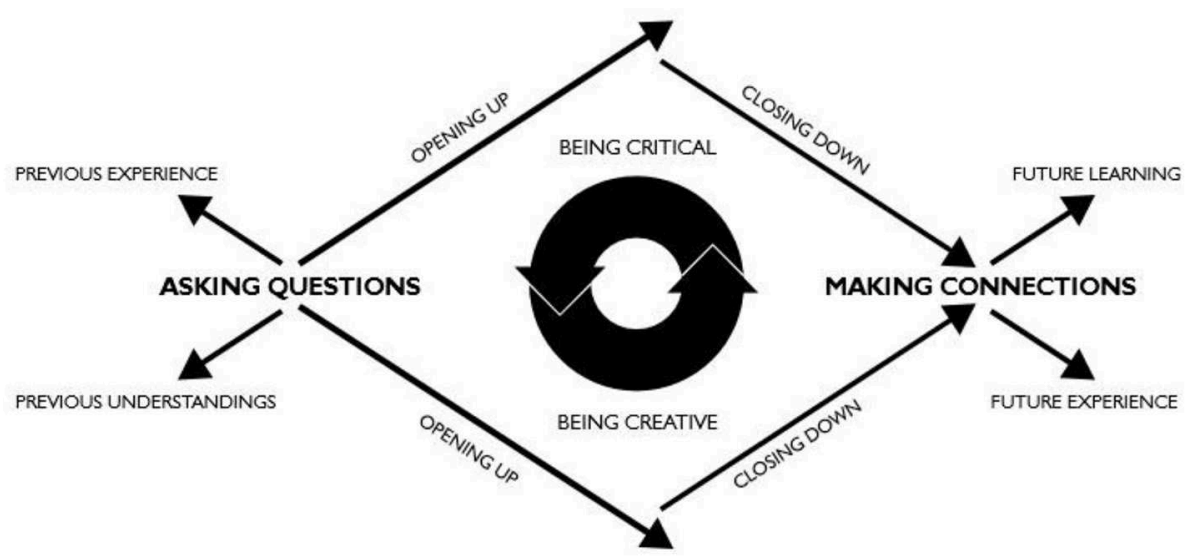

FIGURE 1 | Questions to connections. Reproduced with permission from Freestone (2007).

\begin{tabular}{|c|c|c|c|}
\hline $\begin{array}{l}\text { Generative } \\
\text { question }\end{array}$ & Label & Description & Curious relations \\
\hline What is it like? & FORM & $\begin{array}{l}\text { Everything has a form with recognizable features which can be } \\
\text { observed, identified and categorized. }\end{array}$ & $\begin{array}{l}\text { Processes/drivers; Mechanisms/Operations; Materials/Properties; } \\
\text { Performance/Functionality; Structures/Arrangements; Wholes/Parts }\end{array}$ \\
\hline How does it work? & FUNCTION & $\begin{array}{l}\text { Everything has a purpose, a role or a way of behaving which can be } \\
\text { investigated, described, and trialed. }\end{array}$ & $\begin{array}{l}\text { Designs/Purposes; Effectiveness/Efficiency; Power/Energy; } \\
\text { Processes/Workings; Roles/Corollaries; Systems/Maintenance }\end{array}$ \\
\hline Why is it like it is? & CAUSATION & $\begin{array}{l}\text { Things do not just happen. There are causal relationships at work } \\
\text { and actions have consequences. }\end{array}$ & $\begin{array}{l}\text { Consequences/mpacts; Contexts/Situations; Motivations/lnspirations; } \\
\text { Outcomes/Conclusions; Patterns/Sequences; Theories/Explanations }\end{array}$ \\
\hline $\begin{array}{l}\text { How is it connected } \\
\text { to other things? }\end{array}$ & CONNECTION & $\begin{array}{l}\text { We live in a connected world of interacting systems in which the } \\
\text { actions of any individual element affect others. }\end{array}$ & $\begin{array}{l}\text { Circumstances/Conditions; Initiatives/Opportunities; Power/Motivation } \\
\text { Networks/Relationships; } n \text {; Intentions/Benefits; Systems/Sustainabilty }\end{array}$ \\
\hline How is it changing? & CHANGE & $\begin{array}{l}\text { Change is a process of moving from one state to another. It is } \\
\text { universal and inevitable. }\end{array}$ & $\begin{array}{l}\text { Adaptability/flexibility; Factors/Influences; Growth/Development; } \\
\text { Movement/Flow; Cycles/Sequences; Transform/Redesign }\end{array}$ \\
\hline $\begin{array}{l}\text { What is the role of } \\
\text { place here? }\end{array}$ & PLACE & $\begin{array}{l}\text { Time, space, location, situation, circumstance, and environment } \\
\text { affect the ways people and communities can live and work. }\end{array}$ & $\begin{array}{l}\text { Cultures/Backgrounds; Features/Factors; Histories/Circumstances; } \\
\text { Interactions/Relationships; Resources/Infrastructures; Sites/Locations }\end{array}$ \\
\hline $\begin{array}{l}\text { Who might be } \\
\text { responsible? }\end{array}$ & RESPONSIBILTYY & $\begin{array}{l}\text { People are not passive observers. They make choices and assume } \\
\text { roles, which affect their lives and that of others. }\end{array}$ & $\begin{array}{l}\text { Citizenship//Rights; Justice/Prejudice; Opinions/Decisions; } \\
\text { Participation/Initiative; Personal/Collective; Personalities/Affinities }\end{array}$ \\
\hline $\begin{array}{l}\text { How might people } \\
\text { care for each other? }\end{array}$ & CARE & $\begin{array}{l}\text { Caring for others is a key aspect of healthy communities. It draws on } \\
\text { a sense of empathy, understanding and appreciation. }\end{array}$ & $\begin{array}{l}\text { Empathy/Understanding; Friendship/Compassion; Needs/Assistance } \\
\text { Principles/Passions; Cooperation/Respect; Rights/Responsibilities }\end{array}$ \\
\hline $\begin{array}{l}\text { Where is the ethical } \\
\text { reasoning? }\end{array}$ & ETHICAL & $\begin{array}{l}\text { Ethical consideration is concerned with moral values and beliefs held } \\
\text { and enacted by individuals, communities, and societies. }\end{array}$ & $\begin{array}{l}\text { Beliefs/Traditions; Outcomes/Impacts; Equity/Equality; } \\
\text { Justifications/Rightness; Diversities/Decisions; Values/Moralities }\end{array}$ \\
\hline $\begin{array}{l}\text { How is aesthetic } \\
\text { sense manifest? }\end{array}$ & AESTHETIC & $\begin{array}{l}\text { Aesthetic sense cultivates and values refinement, expression, } \\
\text { sweetness, beauty, flexibility, design, and appeal. }\end{array}$ & $\begin{array}{l}\text { Appeal/Attraction; Designs/Formats; Images/Messages; } \\
\text { Realism/Interpretation; Relationships/Linkages; Style/Flair }\end{array}$ \\
\hline $\begin{array}{l}\text { How is the thinking } \\
\text { evolving? }\end{array}$ & THINKING & $\begin{array}{l}\text { Thinking is how people make sense of experience as well as create } \\
\text { new ideas and ways of doing things. It is seldom static. }\end{array}$ & \begin{tabular}{|l} 
Alternatives/Possibilities; Critical/Creative; Imaginative/IIventive; \\
Issues/Contradictions; Reflections/Tensions; order/disorder
\end{tabular} \\
\hline $\begin{array}{l}\text { What might } \\
\text { innovation add? }\end{array}$ & INNOVATION & $\begin{array}{l}\text { To address challenges new or different ideas and ways of acting may } \\
\text { be needed. Creativity and imagination are central. }\end{array}$ & $\begin{array}{l}\text { Creativity/Improvisation; Flexibility/Adaptation; Novel/Pragmatic; } \\
\text { Originality/Concept; Prototypes/Resources; Research/Collaboration }\end{array}$ \\
\hline
\end{tabular}

FIGURE 2 | Generic generative questions. Reproduced with permission from Freestone (2018).

*For instance, what is said in the Australian Curriculum (ACARA) for year 6 around-persuasive language and engaging with texts.

Example 2. A study focusing on being numerate in percentage and its applications.

If the GGQs selected were-How does it work? and How is it changing? - a "consequent question" might be-In what ways can percentage values be computed and applied? Subject-matters for inquiry might include determining likes and dislikes from food preferences to media programs to physical activities.

If the GGQs were-How is it connected to other things? and What is it like?-a "consequent question" might be-In what ways can the graphing of percentage values influence the impression given in terms of relative proportions and ratios? Subject-matters for inquiry might include investigation into how percentage, proportion and ratio are presented in everyday life and technical reports.

* For instance, what is said in the Australian Curriculum (ACARA) for year 6 around-ratio and rate, and data representation. 
Example 3. A study focusing on personal and community health.

If the GGQs selected were-Why is it like it is? and What might innovation add? - a "consequent question" might be-In what ways can people act to improve and maintain their health? Subject-matters for inquiry might include investigating sports developments, well-being and good dietary practices.

If the GGQs were-How is it connected to other things? and What is the role of place here?-a "consequent question" might be-In what ways do cultural, geographical and lifestyle issues affect personal and community health? Subject-matters for inquiry might include investigation around health issues and problems in different situations, places, and countries.

* For instance, what is said in the Australian Curriculum (ACARA) for year 6 around-questions and prediction and the influence of science (Australian Curriculum Assessment and Reporting Authority (ACARA), 2015a)

Example 4. A study focusing on being knowledgeable about historical perspectives.

If the GGQs selected were-How is it connected to other things? and What is the role of place here?-a "consequent question" might be-In what ways can we pattern trends and events in Australia over the last two hundred and fifty years? Subject-matters for inquiry might include exploration of cultural traditions and practices among migrants and Aboriginal peoples.

If the GGQs were-How is it changing? and How is the thinking evolving? - a "consequent question" might be-In what ways have social practices been evolving in different countries over the last hundred years? Subject-matters for inquiry might include investigation how social habits, practices and entertainment choices affect our lives today and those of people in the past.

*For instance, what is said in the Australian Curriculum (ACARA) for year 6 around-history questions and research, and research skills.

Example 5. A study on being expressive with the aid of digital technologies.

If the GGQs selected were-How is aesthetic sense manifest? and How is thinking evolving? - a "consequent question" might beIn what ways can designs and images be presented online for different audiences? Subject-matters for inquiry might include selecting and using digital tools to create visual images, graphical representations, and animations that convey specific messages.

If the GGQs were-Where is the ethical reasoning? and What might innovation add? - a "consequent question" might be-In what ways might the development and use of smart technologies affect our lives, now and in the future? Subject-matters for inquiry could include investigation of how technological advances in mobile phones affect interactions among people and communities.

* For instance, what is said in the Australian Curriculum (ACARA) for year 6 around-creating literature and research skills.

GGQs are analogous to "inquiry throughlines" in that they enhance learning by adding purpose and direction to studies.
They represent means and ends for learning. They fulfill a similar function to generative topics and understanding goals which are central to a given discipline or subject area (Perkins and Blythe, 1994; Blythe, 1998). The difference is that the GGQs come from a pedagogical perspective of thinking and questioning more than from an epistemological one. Experience in schools has shown that selection of two GGQs for any given study is optimum, more becomes unmanageable and dilutes clarity of purpose.

In recent times, increased emphasis has been placed on knowledge building and knowledge creation being a collaborative process of inquiry (Hmelo-Silver Rutgers and Barrows, 2008; Bereiter and Scardamalia, 2014; Gutiérrez-Braojos et al., 2019). The shift has been toward knowledge construction, as distinct from knowledge assimilation and transmission. Integral to this process is the development of communities of learners characterized by shared endeavors and much social learning (Vygotsky, 1978; DuFour, 2004; Wenger, 2010; Watanabe-Crocket, 2019).

Calls to develop "twenty-first century" skills go back two decades, and a variety of frameworks to describe them have evolved over this period (Galbreath, 1999; Stuart and Dahm, 1999; Dede, 2010; Griffin and Care, 2014). In the past, the conversation created a sense of mission, now it has morphed into finding teaching and learning strategies to develop them (Boss, 2019). GGQs represent both means and ends for developing life-long capabilities embodied in critical and creative thinking, problem-solving and innovation, social interaction and collaboration, and ethical reasoning (Beetham and Sharpe, 2007). They provide a unity of intention while maintaining diversity in learners' inquiries. In so doing they enable diverse inquiry tasks to be distributed to individual learners and groups of learners within school settings (Jarvela et al., 2008), and maybe through Massive Open Online Courses (MOOCs).

Discussions among learners when posing GGQs would likely be mirrored in the sophistication with which "consequent questions" are framed. The sense-making inherent in this process informs learners on how best to conduct their inquiries and the kinds of digital resources they could use. Opportunities to make choices like these corresponds well with decision-making that is part of life and work in the complex world outside school (Resnick, 1987; Dintersmith, 2018).

The relative sophistication of "consequent questions" can be assessed based on principles synthesized from the SOLO (Structure of Observed Learning Outcomes) taxonomy (Biggs and Collis, 1982). That is, do these questions stimulate:

- Making observations-where a few aspects are observed without any links or associations between them

- Seeking explanations-where many relevant aspects are identified with limited associations between them

- Pursuing interrelationships-where different aspects and their dynamics are interrelated or clustered together

- Formulating extrapolations-where aspects and their dynamics are patterned and generalized to different contexts.

In contrast to the categorizations in Blooms taxonomy (Bloom et al., 1956), or variations of it (Anderson and Krathwohl, 2001), 
SOLO digs into how learners are learning as revealed through their performance (DeWitt, 2014).

\section{SMART PROSPECTS}

The capacity of digital tools and resources to give expression to learners' creativity and imagination is well-established (Ringstaff and Yocam, 1996; Camarda, 2016; Anshari et al., 2017). Opportunities for learners to-access ideas and information, amplify ideas and information, transform ideas, and information, and share ideas and information are enhanced (Dwyer, 1994; Freestone, 1997). Yet seldom are digital tools used in schools to articulate inquiry questions or depict images of inquiry designs and practices.

While everyday questions such as-what, why, how, where, when, and who-may be reflected in results learners glean from queries to Internet search engines, the algorithms are designed around meta-tagged words and the frequency with which items of data are accessed. Although plausible answers to questions like "what can we learn from social media?" are now emerging, essentially search engines still abbreviate questions and decompose them into their components such as keywords. Such decomposition is counter to prolonging inquiry. Other online resources such as social media, blogging, video-conferencing do not of themselves relegate questions to casualties in the pursuit of answers (Burnage and Persaud, 2012). Indeed, the interaction they afford has the potential to be dialogical and synthetic, and question driven.

Content-based digital resources like videos, podcasts, and websites also contribute to the scope and depth of learning. To be interactive these resources need to give sufficient time for learners to formulate their own questions (Wachtier et al., 2016). Yet the flow of issues addressed in many these resources is too fast to allow this to happen, which reflects an information and answer driven ethos. The irony is that calls to develop digital software systems structured in ways that provoke questioning among users have been incubating for some time.

\footnotetext{
"We propose reversing the order of things. What if ... questions were more important than answers? What if the key to learning were not the application of techniques but their invention? What if students were asking questions about things that really mattered to them?" (Thomas and Brown, 2011).
}

Development of question driven "smart" software systems might add to, or maybe replace, current information-based search engines (European Commission, 2018). If these smart systems were designed around questions, the thinking and acting involved in sense-making (Ancona, 2014) might be enriched with learners oscillating in a seamless way between being consumers and creators of digital material (Wormell, 2015).

Figure 3 represents a frame of reference for designing and developing question driven programs, resources and experiences. The model has four domains-simple which represents "known knowns," complicated which represents "known unknowns," complex which represents "unknown unknowns," and chaotic which signifies over-all uncertainty (Snowden and Boone,

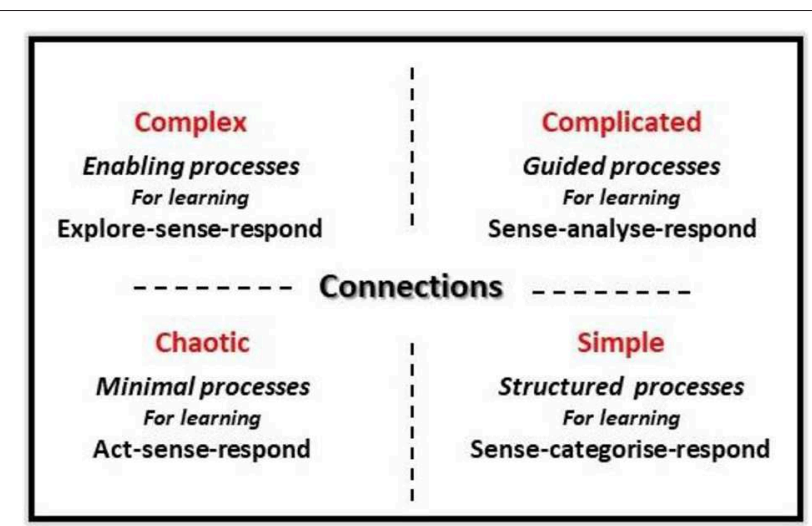

FIGURE 3 | Frame of reference. Reproduced with permission from Freestone and Mason (2019), inspired by the Cynefin Framework (Snowden, 2010).

2007). Each domain has a set of activities comprising different orders and combinations of sense-making, analysis, explanation, categorization and response.

"Connections" has been placed at the center which is consistent with the view that questioning and thinking are concerned with making connections, not necessarily coming up with answers or decisions. To nuance the model for educational settings, each domain has a distinguishing form of inquiry; that is, enabling processes, guided processes, structured processes, and minimal processes. Disciplines of mind derived from different fields of knowledge and experience (Gardner, 1991) are part of the meaning, but not the whole. The tenor of "the action" is pedagogical as distinct from epistemological.

The relative prominence of each domain in an inquiry varies. For instance, the "simple domain" might be in focus if the subject-matter is required to be understood with appropriate skills developed. At the other end of the spectrum, the "chaotic domain" might be superordinate when learners are engaged in uninhibited self-directed challenges. No inquiry is exclusively one or the other, the issue is one of priority in relation the questions posed and the subject-matters under investigation. Balance between the domains might be a key issue for developers of smart digital environments and learning resources.

Figure 4 indicates how GGQs might become embedded in learning programs, resources and activities. Each of the interrelated considerations is equally important; one being mutually supportive of the others. Their enactment is iterative, not lock-step. Clarity of-intention, knowledge, structure and action-is an essential part of intelligent teaching and learning through which learners can formulate "concatenates of sense" and develop deep understanding. Making decisions around each of them is also a challenge and an opportunity for designers of smart digital environments and learning resources.

The four considerations represent what teachers and learners in schools do. They are not shrouded in curriculum abstractions, informative though some of these might be. Dichotomous arguments between subject-centered, teacher-centered, and learner-centered are avoided (Yang and Lin, 2016). Dysfunctional 


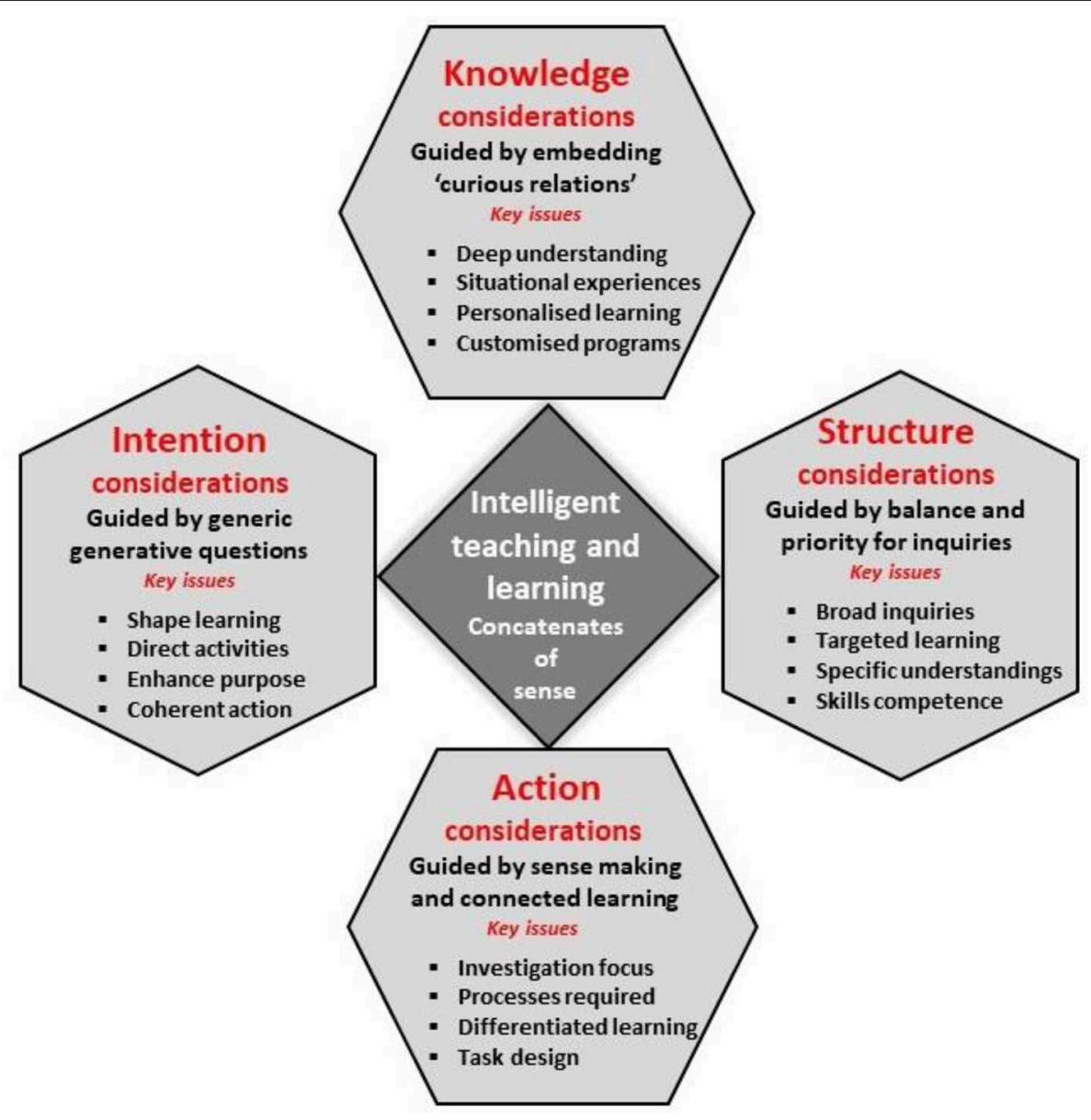

FIGURE 4 | Interrelated considerations. Reproduced with permission from Freestone and Mason (2019).

distinctions between process and product models for curriculum development (Jakes, 2017) and interminable lists of aims and objectives (Tyler, 1949) which frequently appear as criteria linked to prescriptions of content, are also side-stepped. In contrast, these considerations are inclusive of pedagogical realities involved in, for example, problem-solving studies (Fiore et al., 2018), negotiated delivery (Boomer, 1992; Nelken et al., 2013), backward mapping against intentions for learning (Aviles and Grayson, 2017), and constructing learning around multiple intelligences (Gardner, 1983).

It is almost axiomatic to say that digital environments will continue to burgeon with significant impacts on almost all aspects of life and work in modern societies. The ideas presented in this paper highlight the need to develop smart teaching and learning experiences and resources that promote questioning and thoughtful inquiries. A scenario very different from information-based systems or superficial activity on social networking platforms would be created. In so doing, the realities that follow need to be addressed in sustained ways.

"Analysis of the Program for International Student Assessment (PISA) 2003 and 2012 data on the effects of ICT on students' outcomes adds to the sobering picture. The introduction of digital technologies in schools has not yet delivered the promised improvements of better results at lower cost" (OECD, 2016).

"The new pedagogies require students to create new knowledge and connect it to the world by using the power of digital tools" (Fullan and Langworthy, 2014).

"Professional learning is strongly shaped by the context in which the teacher practices. This is usually the classroom, which, in turn, is strongly influenced by the wider school culture and the community and society in which the school is situated" (Timperley, 2008).

Scaffolding learning around GGQs-informed by the frame of reference in Figure 3, and the interrelated considerations in Figure 4-might help enact calls to improve the construction and creation knowledge across the gamut of human experience.

\section{FUTURE RESEARCH}

The potential of smart environments to provide new vistas for teaching and learning is already established within academic 
discourse through journals specifically dedicated to this field (Spector, 2016; Saunders et al., 2017; Kumar, 2018; Martens et al., 2019; McKenna, 2019). The GGQs described in this paper might provide a means or a gateway through which some of this potential might be harnessed. To this end much research is needed to identify realistic and effective ways GGQs can become integral to teaching and learning practices. Key questions include:

- In what ways might GGQs stimulate consequent questions at different stages in inquiries?

- In what ways might GGQs enhance personalized learning and customization of learning programs?

- In what ways might inquiries facilitated by GGQs provide creative insights among learners that help identify areas for further learning?

- In what ways might digital scaffolding be employed to support active engagement in dialog around GGQs?

Given the complexity of human systems like education, design-based research (Barab and Squire, 2004; Herrington et al., 2011; Anderson and Shattuck, 2012) combined with action-based research (Kemmis and McTaggart, 1998) and "appreciative inquiry" (Cooperrider, 2016) could make a significant contribution to informing action at school and classroom levels. Effective practices could be distilled through professional collaboration, formative assessment tools and supportive professional learning environments; thereby, sharing good practices across systems as well as within schools (Gonski

\section{REFERENCES}

Ancona, D. (2014). Sensemaking_Framing and Acting in the Unknown. MIT Sloan School of Management. Available online at: https://www.sagepub.com/sites/ default/files/upm-binaries/42924_1.pdf

Anderson, L., and Krathwohl, D. A. (2001). Taxonomy for Learning, Teaching and Assessing: A Revision of Bloom's Taxonomy of Educational Objectives. New York, NY: Longman.

Anderson, T., and Shattuck, J. (2012). Design-based research: a decade of progress in education research. Educ. Res. 41, 16-25. doi: 10.3102/0013189X11428813

Anshari, M., Almunawar, M. N., Shahrill, M., Wicaksono, D. K., and Huda, M. (2017). Smartphones usage in the classrooms: learning aid or interference. Educ. Inf. Technol. 22, 3063-3079. doi: 10.1007/s10639-017-9572-7

Australian Curriculum Assessment and Reporting Authority (ACARA) (2015b). Critical and Creative Thinking. Australian Curriculum, Assessment and Reporting Authority. Available online at: https://www.australiancurriculum. edu.au/f-10-curriculum/general-capabilities/critical-and-creative-thinking/ (accessed August 22, 2019).

Australian Curriculum Assessment and Reporting Authority (ACARA) (2015a). Australian Curriculum - Foundation to Year 10. Available online at: http:// www.acara.edu.au/curriculum/development-of-australian-curriculum/ foundation-to-year-10 (accessed August 22, 2019).

Aviles, N., and Grayson, K. (2017). Backward Planning - How Assessment Impacts Teaching and Learning. IDRA Newsletter. Available online at: https://www. idra.org/resource-center/backward-planning-assessment-impacts-teachinglearning/ (accessed August 22, 2019).

Barab, S., and Squire, K. (2004). Design-based research: putting a stake in the ground. J. Learn. Sci. 13, 1-14. doi: 10.1207/s15327809jls1301_1

Barrett, F. L., and Satpute, B. A. (2013). Large scale brain networks in affective and social neuroscience: towards an integrative functional architecture of
Report - Australian Government Department of Education Training, 2018).

Realistic as well as sustainable interrelationships between GGQs, digital environments, extant curriculums and emerging practices might contribute to:

- Questioning among learners becoming a key part of curriculum implementation, especially developing the skills and general capabilities inherent in critical and creative thinking [Australian Curriculum Assessment and Reporting Authority (ACARA), 2015b].

- Sense-making and the depth of understanding learners generate from their inquiries.

- Meeting the needs and aspirations of individual learners and giving their talents scope for development and expression.

- Real-life learning that motivates learners to learn and go on learning within school settings and in life outside school.

- Ethical development and application of learning resources including the construction of supportive environments for teachers and learners.

Questioning communities and smart environments have the potential to create agile "hubs for learning" through which these goals might be realized.

\section{AUTHOR CONTRIBUTIONS}

MF is the lead author and is completing a Ph.D. under the supervision of JM. The work is primarily MF, though it has significant conceptual input from JM.

the brain. Curr. Opin. Neurobiol. 23, 361-372. doi: 10.1016/j.conb.2012. 12.012

Beetham, H., and Sharpe, R. J. (2007). Rethinking Pedagogy for a Digital Age. London: Routledge. doi: 10.4324/97802039 61681

Belland, B. R. (2017). Instruction Scaffolding in STEM Education Strategic and Efficacy Evidence. Cham: Springer. doi: 10.1007/978-3-31902565-0

Bereiter, C., and Scardamalia, M. (2014). "Knowledge building and knowledge creation: one concept, two hills to climb," in Knowledge Creation in Education. Education Innovation Series, eds S. Tan, H. So, and J. Yeo (Singapore: Springer), 35-52. doi: 10.1007/978-981-287047-6_3

Biggs, J. B., and Collis, K. F. (1982). Evaluating the Quality of Learning - The SOLO Taxonomy (Structure of the Observed Learning Outcome). New York, NY: Educational Services; Academic Press.

Bloom, B. S, Engelhart, M. D., Furst, E. J., Hill, W. H., and Krathwohl, D. R. (1956). A Taxonomy of Educational Objectives 1: Cognitive Domain. London: Longmans.

Blythe, T. (1998). The Teaching for Understanding Guide. San Francisco, CA: Jossey-Bass Publishers.

Bogler, M. (2018). How to Improve Collaboration, Communication, Creative and Critical Thinking in Students. Project Pals. Available online at: https://www. projectpals.com/project-based-learning-blog/how-to-improve-collaborationcommunication-creative-and-critical-thinking-in-students (accessed August 22, 2019).

Boomer, G. (1992). Negotiating the Curriculum. London: Taylor Francis.

Boss, S. (2019). So Why Do 21st Century Skills Still Matter? Ed Surge. Available online at: https://www.edsurge.com/news/2019-01-22-its-2019-so-why-do21st-century-skills-still-matter (accessed August 22, 2019). 
Bray, B., and McClaskey, K. (2017). Personaization vs. Differentiation vs. Individualization. Available online at: https://education.alberta.ca/media/ 3069745/personalizationvsdifferentiationvsindividualization.pdf (accessed August 22, 2019).

Brogaard, B., and Gatzia, D. E. (2017). Unconscious imagination and the mental imagery debate. Front. Psychol. 8:799. doi: 10.3389/fpsyg.2017. 00799

Burnage, A., and Persaud, R. (2012). Exploring Social Media as a Tool for Knowledge Exchange: The \#btr11 Experiment. Discussion Paper. Birmingham: University of Birmingham. Available online at: http://epapers.bham.ac.uk/ $1793 /$

Camarda, C. (2016). Digital Transformation of Learning - We Need Another 'Apollo Effect'. NASA, White Paper. Available online at: https://www.valamis.com/ resources/whitepapers/digital-transformation-of-learning-white-paper

Chin, C., and Osborne, J. (2008). Students' questions: a potential resource for teaching and learning science. Stud. Sci. Educ. 44, 1-39. doi: 10.1080/03057260701828101

Cooperrider, D. L. (2016). What is Appreciative Inquiry? Retrieved from: http:// www.davidcooperrider.com/ai-process/ (accessed August 22, 2019).

Corley, M. A., and Rauscher, C. (2013). "Deeper learning through questioning," in Georgia Adult Education Conference, TEAL Fact Sheet No 12, Teaching Excellence in Adult Literacy (Washington, DC).

Cotton, K. (1998). Classroom Questioning. North West Regional Education Laboratory.

Dede, C. (2010). "Comparing frameworks for 21st century skills," in 21st Century Skills: Rethinking How Students Learn, eds J. Bellanca and R. Brandt (Bloomington, IN: Solution Tree Press), 51-75.

DeWitt, P. (2014). What's Our Best Taxonomy? Bloom's or SOLO? Education Week. Available online at: https://blogs.edweek.org/edweek/finding_common_ ground/2014/02/whats_our_best_taxonomy_blooms_or_solo.html (accessed August 22, 2019).

Dintersmith, T. (2018). "How can schools best prepare students for the future? Give them real work to do," in Ted Talks. Available online at: https://ideas.ted. com/how-can-schools- best- prepare-students-for-the-future-give-them-realwork-to-do/ (accessed August 22, 2019).

DuFour, R. (2004). "Schools as learning communities," in Reshaping Learning. New Frontiers of Educational Research, eds R. Huang, Kinshuk, and J. M. Spector (Berlin; Heidelberg: Springer), 6-11.

Dwyer, D. (1994). Apple Classrooms of Tomorrow: What We've Learned. ASCD.

Erickson, H. L. (2012). Concept-Based Teaching and Learning, Position Paper. Geneva: International Baccalaureate Organization.

Eris, O. (2003). "Asking generative design questions: a fundamental cognitive mechanism of design thinking," in International Conference on Engineering Design, ICED (Stockholm), 12-21.

European Commission (2018). Next Generation Internet. Available online at: https://www.ngi.eu/resources/ec-calls/ (accessed August 22, 2019).

Fiore, S. M., Graesser, A., and Greiff, S. (2018). Collaborative problem-solving education for the twenty-first-century workforce. Nat. Hum. Behav. 2, 367-369. doi: 10.1038/s41562-018-0363-y

Freestone, M. (1997). Computers as Tools for Teaching and Learning - Department of Education. Hobart, TAS: Department of Education.

Freestone, M. (2007). Thinking for Understanding. Minneapolis, MI: Designshare.

Freestone, M. (2016). Questions Drive Inquiry. Saorcloc Learning. Available online at: https://docs.wixstatic.com/ugd/0dc200_ 0a863168ab404a4f8fffa629ce2f91d9.pdf (accessed August 22, 2019).

Freestone, M. (2018). Curriculum improvisation. Austr. Educ. Lead. 40, 35-39.

Freestone, M., and Mason, J. (2019). "Questions and ethical dilemmas within a design-based research project," in Proceedings of the 27th International Conference on Computers in Education. Taiwan: Asia-Pacific Society for Computers in Education.

Freire, P. (1970). Pedagogy of the Oppressed. New York, NY: Herder and Herder.

Fullan, M., and Langworthy, M. (2014). A Rich Seam: How New Pedagogies Find Deep Learning. London: Pearson Education.

Galbreath, J. (1999). Preparing the 21st century worker: the link between computer-based technology and future skills sets. Educ. Technol. 39, 14-22.

Gardner, H. (1983). Frames of Mind: The Theory of Multiple Intelligence. New York, NY: Basic Books.

Gardner, H. (1991). The Unschooled Mind. New York, NY: Basic Books.
Gonski Report - Australian Government Department of Education and Training. (2018). Through Growth to Achievement: Report of the Review to Achieve Educational Excellence in Australian Schools. Canberra, ACT: Commonwealth of Australia.

Graesser, A., Ozum, Y., and Sullins, J. (2010). "What is a good question?, in Bringing Reading Research to Life, eds M. McKeown and L. Kucan (New York, NY: Guilford Press), 125-126.

Graesser, A. C., and Person, N. K. (1994). Question asking during tutoring. Am. Educ. Res. J. 31, 104-137. doi: 10.3102/00028312031001104

Griffin, P., and Care, E. (eds.). (2014). Assessment and Teaching of 21st Century Skills: Methods and Approach. Dordrecht: Springer. doi: 10.1007/978-94-017-9395-7

Guan Eng Ho, D. (2005). Why do teachers ask the questions they ask? SAGE J. 36, 297-310. doi: 10.1177/0033688205060052

Gutiérrez-Braojos, C., Montejo-Gámez, J., Ma, L., Chen, B., de EscalonaFernández, M. M., Scardamalia, M., et al. (2019). "Exploring collective cognitive responsibility through the emergence and flow of forms of engagement in a knowledge building community," in Didactics of Smart Pedagogy, ed L. Daniela (Cham: Springer), 213-232. doi: 10.1007/978-3-030-0155 1-0_11

Herrington, J., McKenny, S., Reeves, T., and Oliver, R. (2011). "Design-based research and doctoral students: guidelines for preparation a dissertation proposal, research," in Proceedings of World Conference on Educational Multimedia, Hypermedia and Telecommunications (Perth, WA: Edith Cowan University Publications).

Hmelo-Silver Rutgers, C. E., and Barrows, H. S. (2008). Facilitating collaborative knowledge building. Cogn. Instruct. 26, 48-94. doi: 10.1080/07370000701798495

Hmelo-Silver, C. E., Duncan, R. G., and Chinn, C. A. (2007). Scaffolding and achievement in problem-based and inquiry learning: a response to Kirschner, Sweller, and Clark (2006). Educ. Psychol. 42, 99-107. doi: 10.1080/00461520701263368

IBO (2000). Making the Primary Years Program (PYP) Happen. Geneva: International Baccalaureate Organisation.

Jakes, D. (2017). Process vs. Product. Clarity Innovations. Available online at: https://www.k12blueprint.com/blog/david-jakes/product-vs-process (accessed August 22, 2019)

Jarvela, S., Jar̈venoja, H. J., and Veermans, M. (2008). Understanding the dynamics of motivation in socially shared learning. Int. J. Educ. Res. 47, 122-135. doi: 10.1016/j.ijer.2007.11.012

Kemmis, S., and McTaggart, K. (eds.). (1998). The Action Research Planner. Geelong, VIC: Deakin University Press.

Khan, K., and Mason, J. (2015). "Sense-making, mathematics, and digital technology," in Proceedings of the Global Conference on Teaching and Learning With Technology, eds R. Dillon and L. M. Tan (Singapore: World Scientific Publishing), 35-45. doi: 10.1142/978981473359 50003

Klanlari, A., Resendes, M., Zhu, G., and Scardamalia, M. (2017). Productive Knowledge Building Discourse Through Student-Generated Questions. Philadelphia, PA: International Society of the Learning Sciences, 585-588. doi: $10.22318 / \operatorname{cscl} 2017.84$

Kumar, K. (2018). Advancing learning through smart learning analytics: a review of case studies. Asian Assoc. Open Univers. J. 13, 1-12. doi: 10.1108/AAOUJ-12-2017-0039

Lakoff,. G. (eds.). (1993). The Contemporary Use of Metaphor, Metaphor and Thought. New York, NY: Cambridge University Press.

Martens, A., Sandkuhl, K., Lantow, B., Lehmann, H., Lettau, W.-D., and Radisch, F. (2019). An evaluation approach for smart support of teaching and learning processes. Smart Learn. Environ. 6:2. doi: 10.1186/s40561-0180081-y

Mason, J. (2011). Scaffolding reflective inquiry - enabling why-questioning while e-learning. Res. Pract. Technol. Enhanc. Learn. 7, 175-198.

Mason, J. (2012). "Theorizing why in e-learning - a frontier for cognitive engagement," in Proceedings IADIS International Conference on Cognition and Exploratory Learning (CELDA), eds D. Sampson, J. M. Spector, D. Ifenthaler, and P. Isaias (Madrid), 57-64.

Mason, J. (2014a). "'Does it make sense' and 'What does it mean"' in Proc 22nd International Conference on Computers in Education (ICCE) (Hangzhou). 
Mason, J. (2014b). "Theorizing why in digital learning," in Digital Systems and Open Access to Formal and Informal Learning, eds D. Sampson, D. Ifenthaler, M. Spector, and P. Isaias (Zurich: Springer), 101-118.

Mason, J. (2014c). The why dimension - opening frontiers for digital learning (Doctoral thesis). Queensland University of Technology, Brisbane, QLD, Australia. Retrieved from: https://eprints.qut.edu.au/70093/1/Jonathan_ Mason_Thesis.pdf

McGill, V. J., and Parry, W. T. (1948). The unity of opposites: a dialectical principle. Sci. Soc. 12, 418-444.

McKenna, P. (2019). Multiple choice questions: answering correctly and knowing the answer. Interact. Technol. Smart Educ. 16, 59-73. doi: 10.1108/ITSE-09-2018-0071

Moreno, R., and Mayer, R. (2007). Interactive multimodal learning environments special issue on interactive learning environments: contemporary issues and trends. Educ. Psychol. Rev. 19, 309-326. doi: 10.1007/s10648-007-9047-2

Nair, P. (2018). Redesigning Schools Into Student-Directed Learning Communities. The Education Alliance; Brown University. Available online at: https:// www.fieldingnair.com/wp-content/uploads/2019/03/Article-Prakash-NairEducadores-Journal.pdf

Nelken, M., McAdoo, B., and Manwaring, M. (2013). Negotiating Learning Environments. Saint Paul, MN: Hamline Open Access.

OECD (2016). Innovating Education and Educating for Innovation - The Power of Digital Technologies and Skills. Paris: OECD.

Paivio, A. (1986). Mental Representations: A Dual Coding Approach. New York, NY: Oxford University Press.

Pendleton-Jullian, A. M., Brown, J. S., Bowker, G. C., and Edwards, P. N. (2018). Design Unbound: Designing for Emergence in a White Water World. Cambridge, MA: MIT Press. doi: 10.7551/mitpress/10592.001.0001

Perkins, D., and Blythe, T. (1994). Putting understanding up front. Educ. Leadersh. 51, 4-7.

Perveen, A. (2018). Facilitating multiple intelligences through multimodal learning analytics. Turk. Online J. Distance Educ. 19, 18-30. doi: 10.17718/tojde.382655

Popham, J. W. (2001). Teaching to the test? Educ. Leadersh. 58, 16-20.

Resnick, L. B. (1987). Learning in school and out. Educ. Res. 16, 13-20. doi: $10.2307 / 1175725$

Ricoeur, P. (1978). The Rule of Metaphor: Multidisciplinary Studies of the Creation of Meaning in Language. London: Routledge and Kegan Paul.

Ringstaff, C., and Yocam, K. (1996). Integrating Technology Into Classroom Instruction: An Assessment of the Impact of the ACOT Teacher Development Center Project. ACOT Report \#22, Apple Classrooms of Tomorrow.

Robinson, K. (2010). RSA ANIMATE: Changing Education Paradigms. Available online at: https://www.youtube.com/watch?v=zDZFcDGpL4U (accessed August 22, 2019).

Robinson, K. (2011). Out of Our Minds: Learning to be Creative. Chichester: Capstone. doi: 10.1002/9780857086549

Rothstein, D., and Santana, L. (2011). Teaching students to ask their own questions. Harvard Educ. Lett. 27, 1-2.

Rudduck, J. (2004). Pupil Voice is Here to Stay! University of Cambridge. Available online at: http://www.qca.org.uk/futures/ (accessed August 22, 2019).

Sahlberg, P. (2015). Finnish Lessons 2.0: What Can the World Learn From Educational Change in Finland. New York, NY: Teachers College Press.

Saunders, G., Oradini, F., and Clements, M. (2017). SMART teaching in new and old classrooms. IAFOR J. Educ. 5, 85-109. doi: 10.22492/ije.5.1.05

Snowden, D. J. (2010). The Cynefin Framework. Cognitive Edge. Available online at: https://www.youtube.com/watch?v=N7oz366X0-8 (accessed August 22, 2019).
Snowden, D. J., and Boone, M. E. (2007). A leader's framework for decision making. Harv. Bus. Rev. 85, 68-76. Available online at: https://hbr.org/2007/ 11/a-leaders-framework-for-decision-making

Spector, B. S. (2017). The Unorthodox Professor. Olney: Brill; Sense. doi: $10.1163 / 9789463511766$

Spector, J. M. (2016). The potential of smart technologies for learning and instruction. Int. J. Smart Technol. Learn. 1, 21-32. doi: 10.1504/IJSMARTTL.2016.078163

Sporns, O. (2010). Networks of the Brain: Quantitative Analysis and Modeling. Available online at: https://www.researchgate.net/profile/Olaf_Sporns/ publication/267378614_Networks_of_the_Brain_Quantitative_Analysis_and_ Modeling/links/55c4a9ce08aea2d9bdc385b8.pdf (accessed August 22, 2019).

Stuart, L., and Dahm, E. (1999). 21st Century Skills for 21st Century Jobs. Washington, DC: Federal Publications, 151.

Sullins, J., Acuff, S., Neely, D., and Hu, X. (2018). When knowledge isn't power: the influence of prior knowledge on question generation training. $J$. Educ. Multimedia Hypermedia 27, 245-265. Available online at: https://www. learntechlib.org/primary/p/181006/

Thomas, D., and Brown, J. S. (2011). A New Culture of Learning: Cultivating the Imagination for a World of Constant Change. Lexington, KY: CreateSpace.

Timperley, H. (2008). Teacher Professional Learning and Development. Geneva; Brussels: UNESCO; International Academy of Education (IAE); International Bureau of Education (IBE).

Tyler, R. (1949). Basic Principles of Curriculum and Instruction. Chicago, IL: The University of Chicago Press Ltd.

UNESCO (2015). Rethinking Education - Towards a Global Common Good. United Nations Educational, Scientific and Cultural Organization.

Vygotsky, L. S. (1978). Mind in Society: The Development of Higher Psychological Processes. Cambridge: Harvard University Press.

Wachtier, J., Hubmann, M., Zohrer, H., and Ebner, M. (2016). An analysis of the use and effect of questions in interactive learning-videos. Smart Learn. Environ. 3:13. doi: 10.1186/s40561-016-0033-3

Watanabe-Crocket, L. (2019). This is Why Making Strong Learning Connections Matters Most. Available online at: https://globaldigitalcitizen.org/makingstrong-learning-connections-matters (accessed August 22, 2019).

Wenger, E. (2010). "Communities of practice and social learning systems: the career of a concept," in Social Learning Systems and Communities of Practice, ed C. Blackmore (London: Springer), 179-198. doi: 10.1007/978-1-84996-133-2_11

Wormell, R. (2015). Moving Students from Passive Consumers to Active Creators. Association for Middle Level Education. Available online at: https://www.amle. org/BrowsebyTopic/WhatsNew/WNDet/TabId/270/ArtMID/888/ArticleID/ 526/Moving-Students-from-Passive-Consumers-to-Active-Creators.aspx (accessed August 22, 2019).

Yang, F., and Lin, J. (2016). A Chinese tai chi model: an integrative model beyond the dichotomy of student-centered learning and teacher-centered learning. Asian Educ. Stud. 1, 44-55. doi: 10.20849/aes.v1i2.61

Conflict of Interest: The authors declare that the research was conducted in the absence of any commercial or financial relationships that could be construed as a potential conflict of interest.

Copyright (C) 2019 Freestone and Mason. This is an open-access article distributed under the terms of the Creative Commons Attribution License (CC BY). The use, distribution or reproduction in other forums is permitted, provided the original author(s) and the copyright owner(s) are credited and that the original publication in this journal is cited, in accordance with accepted academic practice. No use, distribution or reproduction is permitted which does not comply with these terms. 